\title{
DRYING CHARACTERISTICS OF CAP AND STEM OF MUSHROOM
}

\author{
A. Addo, A. Bart-Plange and D. M. Boakye \\ Department of Agricultural Engineering \\ Kwame Nkrumah University of Science and Technology, Kumasi, Ghana
}

\begin{abstract}
Thin-layer drying of cap and stem of mushroom was studied at temperatures of 40, 50 and $60^{\circ} \mathrm{C}$. Drying took place in the falling rate period, and the drying behaviour was adequately described by the Page's equation. The activation energy values of cap and stem were determined to be 26.96 and $26.85 \mathrm{~kJ} / \mathrm{mol}$, respectively. The computed values of frequency factor $\boldsymbol{k}_{o}$ for cap and stem were 4174 and $6247 h^{-1}$, respectively. The higher $k_{o}$ value for stem implied lower resistance to diffusion of moisture and therefore resulted in less drying time for stem at similar moisture content.
\end{abstract}

Keywords: Drying, Mushroom, Page's model

\section{INTRODUCTION}

Mushroom is an important food in the diet of Ghanaians (Atikpo et al., 2008). Mushroom is an excellent source of essential amino acids, vitamins, and minerals and can contribute to the formulation of a balanced diet (Bano and Rajarathnam, 1988; Manzi et al., 2001; Mattila et al., 2001). Therapeutic properties of mushrooms include enhancement of macrophage function and host resistance to many bacterial, viral, fungal, and parasitic infections; activation of a non-specific immune stimulation; and reduction of blood cholesterol and blood glucose levels (Cheung, 1998; Rajarathnam et al., 1998). Mushroom has been found to inhibit aromatase activity and suppress breast cancer cell proliferation (Grube et al., 2001).

Mushrooms are highly perishable as they contain moisture in the range of $87 \%$ to $95 \%$ wet basis. Quality deterioration takes place if fresh mushrooms are not immediately processed. Drying is the most commonly used method of preservation of mushrooms. Dehydrated mushrooms are used as an important ingredient in several food formulations including instant soups, pasta salads, snack seasonings, stuffing, casseroles, and meat and rice dishes (Tuley, 1996). Furthermore, elevated temperatures during drying enhance enzymatic reaction that can result in improved flavour of dehydrated mushrooms (Tuley, 1996). Extending the shelf life of mushrooms is important to mushroom producers and consumers, and drying mushrooms is one method that would extend the shelf life (Tuley, 1996).

The most relevant aspects of drying technology are the mathematical modelling of the process and the equipment. The modelling is basically

88 Journal of Science and Technology, Vol. 29, No. 2, Aug., 2009 
based on the design of a set of equations to describe the system as accurately as possible (Celma et al., 2007). McMinn (2006) outlines several thin layer drying models for explaining drying characteristics of agricultural products. Mathematical models of the drying processes are used for designing new or improving existing drying systems and even for the control of the drying process.

In Ghana mushroom is generally used in the fresh form for the preparation of soups and dehydrated mushrooms are not available in the retail market. But as eating habits begin to change dehydrated mushrooms may become popular in Ghanaian dishes in the future. Therefore, the present study was undertaken to investigate the drying characteristics of cap and stem of Agaricus placomyces variety of mushroom.

\section{MATERIALS AND METHODS Materials and Equipment}

Freshly harvested Agaricus placomyces was purchased from a local market in Kumasi. The samples were washed and air-dried at room temperature for $15 \mathrm{~min}$ for surface moisture removal. The initial moisture contents of four replicates of pieces of cap and stem were determined using hot oven method at $70^{\circ} \mathrm{C}$ for $24 \mathrm{~h}$ (AOAC, 1990).

\section{Drying process}

Cap and stem, of $40 \mathrm{~mm}$ length, were dried at air temperatures of 40,50 and $60^{\circ} \mathrm{C}$ in a ventilated laboratory oven. Weights of samples were recorded at a $30 \mathrm{~min}$ interval for the initial $2 \mathrm{~h}$ and thereafter at $1 \mathrm{~h}$ interval until no change in sample weight was recorded. The moisture content of the sample on wet basis at a defined time was determined using equation (1).

$$
M_{i}=\left(1-\frac{W_{o}\left(1-M_{o}\right)}{W_{i}}\right) \times 100 \%
$$

where,

$M_{i}=$ moisture content at the ith time, $\%$ wet basis

$M_{o}=$ initial moisture content, decimal

$W_{o}=$ initial weight of sample, $\mathrm{g}$

$W_{i}=$ weight of sample at the ith time, $\mathrm{g}$
Mathematical Modelling of Drying Characteristics

The heated-air drying of biological materials in the falling rate period is a diffusion-controlled process and may be represented by Fick's second law of diffusion. Various types of mathematical models have been used to describe the drying of foodstuffs, ranging from theoretical models based on classical diffusion theory to purely empirical models (Pabis, 1999). One equation that has been used successfully to describe drying behaviour of a variety of biological materials (Jayas and Sokhansanj, 1989; ASAE Standards, 1989; Tan et al., 2001; Arora et al., 2003) is Page's equation (Page, 1949):

$$
M R=\frac{M_{t}-M_{e}}{M_{o}-M_{e}}=\exp \left(-k t^{n}\right)
$$

where,

$M R=$ dimensionless moisture ratio (-)

$M_{t}=$ moisture content at any moment $(\%$ dry basis, db)

$M_{o}=$ initial moisture content of product $(\% \mathrm{db})$

$M_{e}=$ equilibrium moisture content

$k=$ rate constant $\left(\mathrm{h}^{-1}\right)$

$t=$ drying time, $\mathrm{h}$

$n=$ constant

Since the values of the equilibrium moisture content, $M_{e}$, are relatively small compared to $M_{t}$ or $M_{o}$, equation (2) can be simplified to equation (3) (Thakor et al., 1999):

$$
M R=\frac{M_{t}}{M_{o}}=\exp \left(-k t^{n}\right)
$$

To determine the constants $k$ and $n$, equation (3) can be expressed in the linear form as follows:

$\operatorname{In}[-\operatorname{In}(M R)]=\operatorname{In}(k)+n \operatorname{In}(t)$

Linear regression of equation (4) was carried out using the least squares technique in Microsoft Excel to determine the constants.

The root mean error (RME) and the root mean square error (RMSE) between the experimental 
and predicted values were calculated using equations (5) and (6) respectively:

$$
\begin{gathered}
R M E=\frac{100}{N} \sum_{i=1}^{N} \frac{\left|M_{\exp i}-M_{\text {cali }}\right|}{M_{\exp i}} \\
R M S E=\sqrt{\frac{1}{N} \sum_{i=1}^{N}\left(M_{\exp i}-M_{\text {cali }}\right)^{2}}
\end{gathered}
$$

where,

$\mathrm{N}=$ the number of observation

$M_{\text {expi }}=$ the experimental moisture ratio at the ith observation.

$M_{\text {cali }}=$ the calculated moisture ratio at the ith observation

\section{RESULTS AND DISCUSSION Drying Rate}

Figures 1 and 2 show the plots of equation (4) which were used to determine the values of the constants as given in Table 1.

The drying rate constant $k$ increased with increasing drying air temperature (Table 1). The values for cap increased from $0.132 \pm 0.041$ to $0.246 \pm 0.028 \mathrm{~h}^{-1}$ whilst the values for stem in- creased from $0.203 \pm 0.011$ to $0.377 \pm 0.021 \mathrm{~h}^{-1}$ when the drying temperature was increased from 40 to $60^{\circ} \mathrm{C}$. This implies that the rate of moisture loss in stem was higher than for cap at each drying air temperature. The difference was due to the more fibrous nature of the stem compared to the cap. The $n$ values for cap increased from $1.4017 \pm 0.112$ to $2.0237 \pm 0.114$ whereas the values for stem decreased from $1.1644 \pm 0.090$ to $1.0299 \pm 0.042$ with increase in temperature. These results are contrary to the inconsistency in $n$ values reported by Arora (2003) for whole Agaricus bisporus as drying temperature was increased.

The calculated values of the constants at each drying air temperature were substituted into equation (2) and the experimental data fitted to the equation. The plots of the experimental and predicted data are shown in Figures 3 and 4. It can be observed that there was no constant rate drying period in the drying of mushroom and all the drying processes are seen to occur in the falling rate period. This indicates that diffusion was the dominant physical mechanism governing moisture movement in the mushroom samples. These results are similar to others pub-

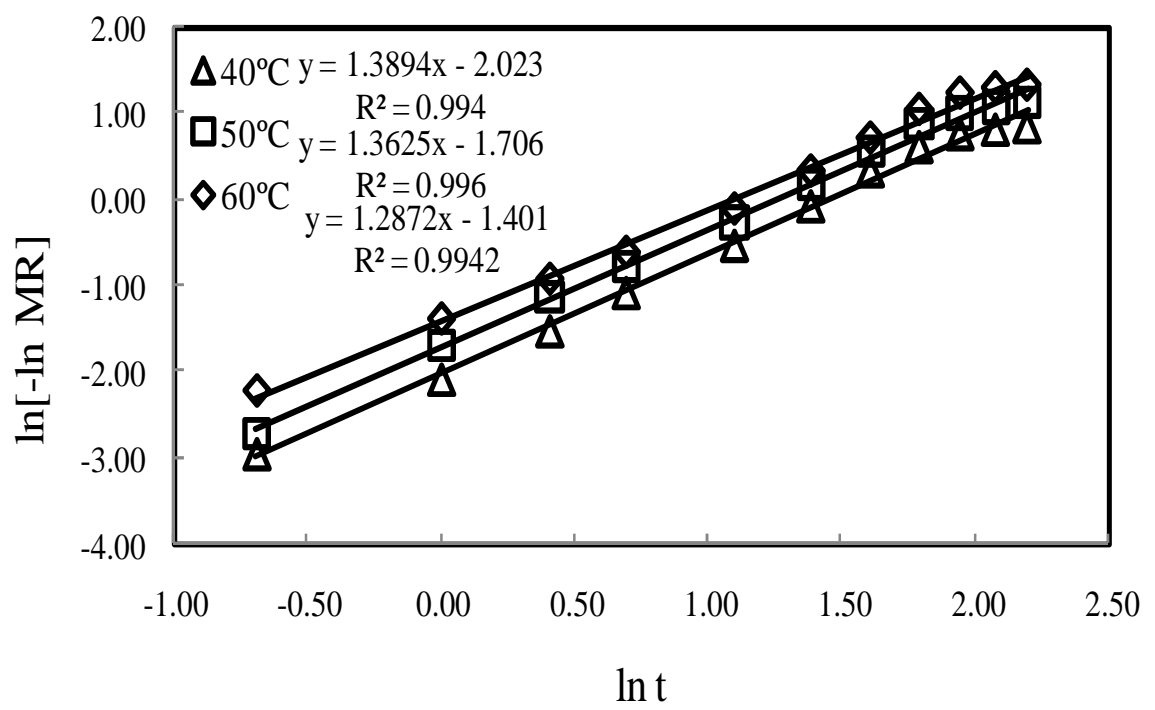

Fig. 1. Relationship between moisture ratio and drying time for the cap of Agaricus placomyces mushroom of Page's model

90 Journal of Science and Technology, Vol. 29, No. 2, Aug., 2009 


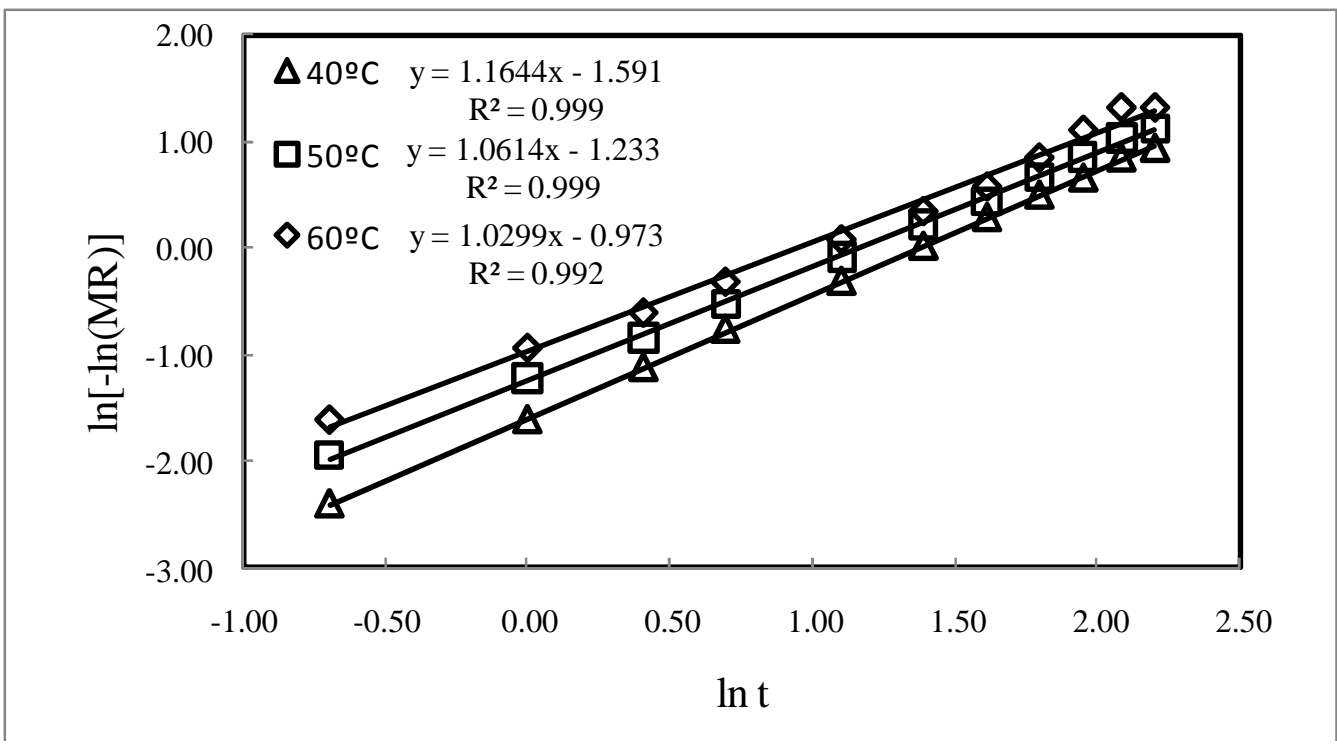

Fig 2. Relationship between moisture ratio and drying time for the stem of Agaricus placomyces mushroom of Page's model

Table 1: Values of coefficients in equation (3)

\begin{tabular}{ccccc}
\hline $\begin{array}{c}\text { Temperature } \\
\left({ }^{\mathbf{}} \mathbf{C}\right)\end{array}$ & $\begin{array}{c}\text { Cap } \\
\text { Drying Rate } \\
\text { Constant } \boldsymbol{k}\left(\mathbf{h}^{\mathbf{- 1}}\right)\end{array}$ & $\mathbf{n}$ & $\begin{array}{l}\text { Srying Rate } \\
\text { Constant } \boldsymbol{k}\left(\mathbf{h}^{-\mathbf{1}}\right)\end{array}$ & $\mathbf{n}$ \\
\hline 40 & $0.132 \pm 0.041$ & $1.4017 \pm 0.112$ & $0.203 \pm 0.011$ & $1.1644 \pm 0.090$ \\
50 & $0.181 \pm 0.023$ & $1.7064 \pm 0.093$ & $0.291 \pm 0.029$ & $1.0614 \pm 0.011$ \\
60 & $0.246 \pm 0.028$ & $2.0237 \pm 0.114$ & $0.377 \pm 0.021$ & $1.0299 \pm 0.042$ \\
\hline
\end{tabular}

The results are reported as mean drying rate constant \pm standard deviation.

lished in the literature on the drying process of vegetables and agricultural products (Doymaz, 2004 for green beans; Madamba et al., 1996 for garlic; Sogi et al., 2003 for tomato seeds).

\section{Effect of Temperature on Drying Character-} istics

Total drying time decreased with increase in drying temperature of the drying air (Figures 3 and 4). The drying rate constant $k$ increased significantly $(\mathrm{p} \leq 0.05)$ with increase in temperature (Table 1). The results suggested that the Arrhenius law may be applicable to relate the dependence of drying constant on drying air temperature $\left(R^{2} \geq 0.994\right)$. The relationship is as follows: $k=k_{o} \exp \left(-\frac{E}{R T}\right)$

where,

$k=$ rate constant $\left(\mathrm{h}^{-1}\right)$

$E=$ activation energy $\left(\mathrm{kJ} \cdot \mathrm{mol}^{-1}\right)$

$k_{o}=$ frequency factor $\left(\mathrm{h}^{-1}\right)$

$R=$ universal gas constant $\left(8.314 \mathrm{~kJ} \cdot \mathrm{mol}^{-1} \cdot \mathrm{K}^{-1}\right)$

$T=$ absolute temperature $(\mathrm{K})$.

The activation energies, as determined from the slope of each curve, for cap and stem were 26.96 and $26.85 \mathrm{~kJ} / \mathrm{mol}$ respectively. The values were more than $19.79 \mathrm{~kJ} / \mathrm{mol}$ reported by Arora (2003) for whole Agaricus bisporus. The 


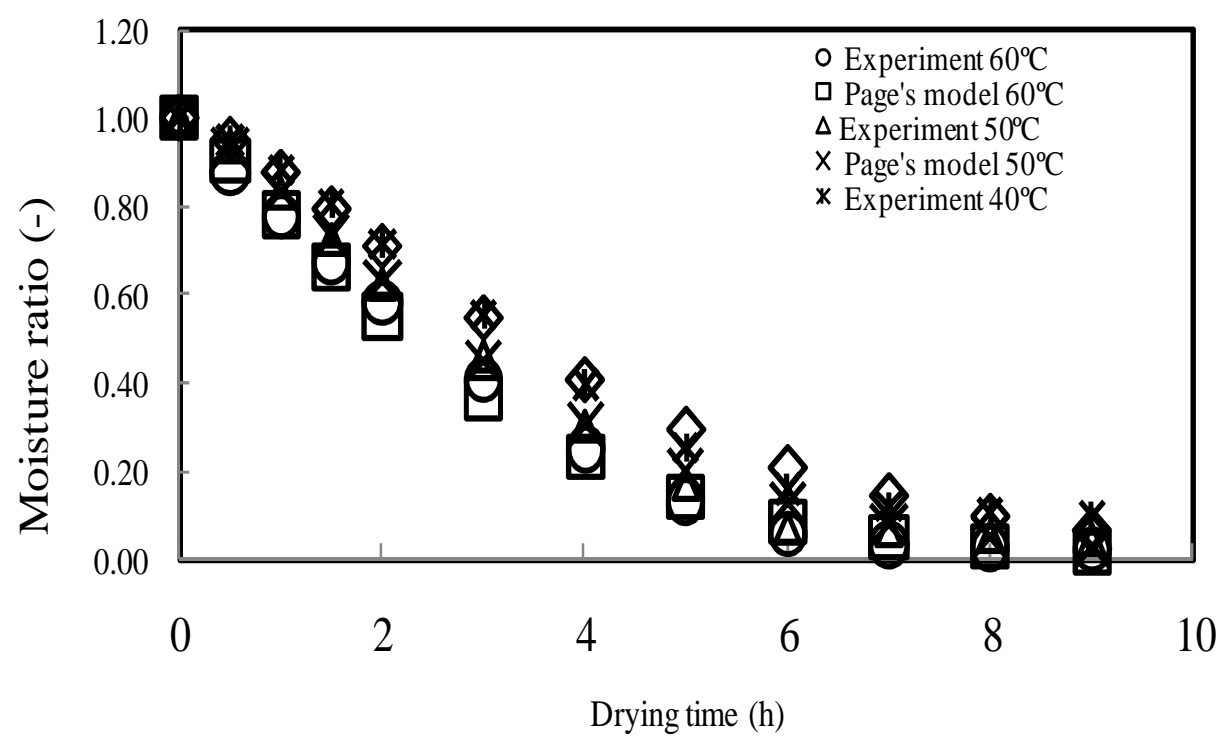

Figure 3. Relationship between moisture ratio and drying time of mushroom cap

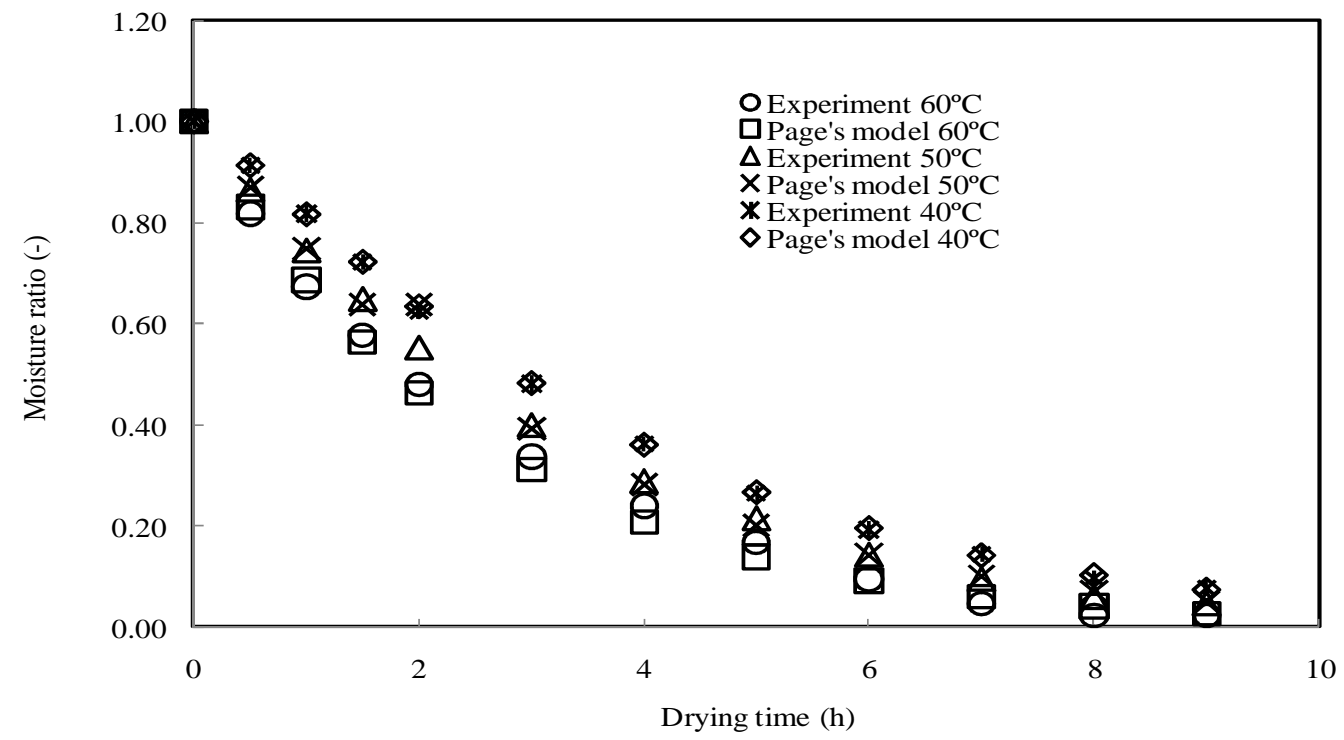

Fig. 4. Relationship between moisture ratio and drying time of mushroom stem

92 Journal of Science and Technology, Vol. 29, No. 2, Aug., 2009 
Table 2: Calculated statistical values between experimental and predicted data

\begin{tabular}{lcccrrr}
\hline \multirow{2}{*}{ Parameter } & \multicolumn{3}{c}{ Cap } & & \multicolumn{3}{c}{ Stem } \\
& $\mathbf{4 0}^{\circ} \mathbf{C}$ & \multicolumn{1}{c}{$\mathbf{5 0}^{\circ} \mathbf{C}$} & $\mathbf{6 0}^{\circ} \mathbf{C}$ & $\mathbf{4 0}^{\circ} \mathbf{C}$ & \multicolumn{1}{c}{$\mathbf{5 0}^{\circ} \mathbf{C}$} & \multicolumn{1}{c}{$\mathbf{6 0}^{\circ} \mathbf{C}$} \\
\hline $\mathrm{R}^{2}$ & 0.994 & 0.995 & 0.994 & 0.992 & 0.999 & 0.999 \\
$\mathrm{RME}$ & 14.122 & 16.521 & 10.871 & 10.852 & 18.720 & 9.556 \\
$\mathrm{RMSE}$ & 0.0182 & 0.0197 & 0.0406 & 0.0188 & 0.0581 & 0.0691 \\
\hline
\end{tabular}

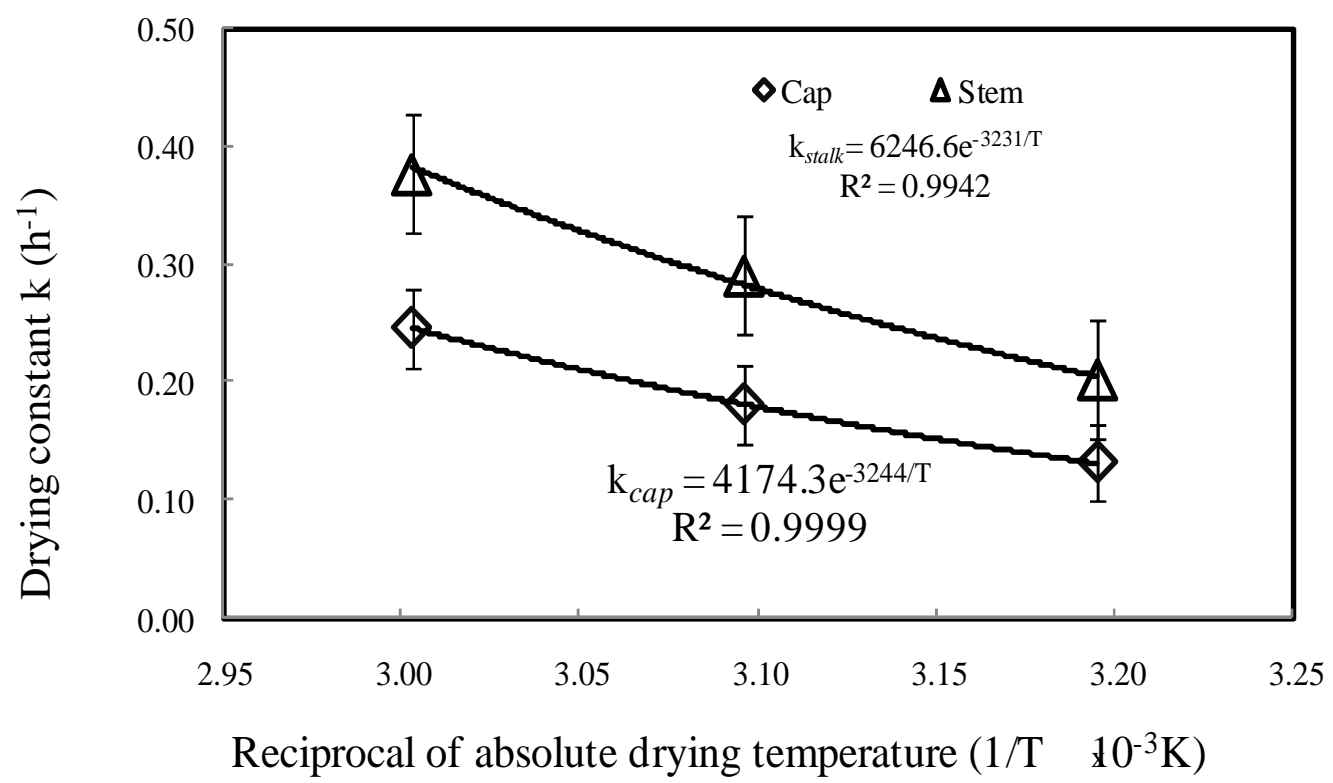

Fig. 5. Arrhenius relationship between drying constant and temperature. Bar represents standard error

difference in value could be due to varietal characteristics and the values reported in both studies are within the range reported by Rizvi (1995) for various foods. The activation energy values of cap and stem were approximately similar; therefore their sensitivity to temperature was the same. The computed values of $k_{o}$ for cap and stem of Agaricus placomyces were 4174 and $6247 \mathrm{~h}^{-1}$, respectively. The higher $k_{o}$ value for stem implies lower resistance to diffusion of moisture. This is supported by final moisture ranges of $0.18-0.75 \% \mathrm{db}$ and $0.10-$ $0.32 \% \mathrm{db}$ for cap and stem respectively at $9 \mathrm{~h}$. The moisture content values of stem at $9 \mathrm{~h}$ were about $50 \%$ lower than for cap.

\section{CONCLUSIONS}

The total drying time of cap and stem of Agaricus placomyces to final moisture ranges of 0.18 $-0.75 \% \mathrm{db}$ and $0.10-0.32 \% \mathrm{db}$ respectively was $9 \mathrm{~h}$. Drying of cap and stem of Agaricus placomyces took place in the falling rate period, 
and the drying behaviour was adequately described by Page's equation. The drying rate constant was related to temperature using the Arrhenius relationship, and the activation energy values of cap and stem of Agaricus placomyces were determined to be 26.96 and 26.85 $\mathrm{kJ} / \mathrm{mol}$, respectively. The computed values of $k_{o}$ for cap and stem were 4174 and $6247 \mathrm{~h}^{-1}$, respectively. The higher $k_{o}$ value for stem implied lower resistance to diffusion of moisture. This was reflected in the final moisture content ranges after $9 \mathrm{~h}$ of drying. The values for stem were $50 \%$ less than for cap. Further study on drying and packaging of mushrooms is being investigated by the authors.

\section{REFERENCES}

Akgun, N. A., and Doymaz, I. (2005). Modelling of olive cake thin-layer drying process. Journal of Food Engineering 68: 455461.

Akpinar, E., Midilli, A., and Bicer, Y. (2003). Single-layer drying behaviour of potato slices in a convective cyclone dryer and mathematical modelling. Energy Conversion and Management 44(10):1689-1705.

AOAC. (1990). Official method of analysis. Washington, DC: Association of Official Analytical Chemists (No. 934.06).

Arora, S., Shivhare, U. S., Ahmed, J. and Raghavan, G. S. V. (2003). Drying kinetics of Agaricus bisporus and Pleurotus florida mushrooms. Transactions of the ASAE 46 (3): 721-724.

ASAE Standards. (1998). S448: Thin-layer drying of grains and small crops. $45^{\text {th }}$ ed. St. Joseph, MICH.: ASAE.

Atikpo, M., Onokpise, O., Abazinge, M., Louime, C., Dzomeku, M., Boateng, L. and Awumbilla, B. (2008). Sustainable mushroom production in Africa: a case study in Ghana. African Journal of Biotechnology 7(3): 249-253.

Bano, Z., and Rajarathnam, S. (1998). Pleurotus mushrooms: Part II. Chemical composition, nutritional value, post-harvest physiology, preservation and role as human food. Critical Review in Food Science and Technology 27(2): 87-158.

Celma, A. R., Rojas S., Lopez F., Montero L., and Miranda T. (2007). Tratamiento energetico de alperujos. Energia 162: 95-100.

Cheung, P.C.K. (1998). Functional properties of edible mushrooms. Journal of Nutrition 128(9): 1512-1516.

Doymaz, I. (2004). Drying kinetics of white mulberry. Journal of Food Engineering 61 (3):341-346.

Grube, B. J., E. T. Eng, K. Yeh-Chih, A. Kwon, and C. Shiuan. (2001). White button mushroom phytochemicals inhibit aromatase activity and breast cancer cell proliferation. Journal of Nutrition 131(12): 3288-3293.

Jayas, D.S., and Sokhansanj, S. (1989). Thinlayer drying of barley at low temperatures. Canadian Journal Agricultural Engineering 31(1): 21-23.

Madamba, P. S., Driscoll, R. H. and Buckle, K. A. (1996). The thin-layer drying characteristics of garlic slices. Journal of Food Engineering 29: 75-97.

Manzi, P., Aguzzi, A. and Pizzoferrato, L. (2001). Nutritional value of mushrooms widely consumed in Italy. Food chemistry 73(3): 321-325.

Mattila, P., Konko, K., Eurola, M., Pihlava, J., Astola, J., Vahteristo, L. and Piironen, V. (2001). Contents of vitamins, mineral contents, and some phenolic compounds in cultivated mushrooms. Journal of Agric. Food Chem. 49(5): 2343-2348.

McMinn, W. A. M. (2006). Thin-layer modelling of the convective, microwave, microwave-convective and microwave vacuum drying of lactose powder. Journal of Food Engineering 72: 113-123.

Midilli, A. and Kucuk, H. (2003). Mathematical modelling of thin layer drying of pistachio by using solar energy. Energy Conversion and Management 44: 1111-1122 
Pabis, S. (1999). The initial phase of convective drying of vegetables and mushrooms and the effect of shrinkage. Journal of Agric. Eng. Res. 72(2): 187-195.

Page, C. (1949). Factors influencing the maximum rate of drying shelled corn in layers. MS thesis. West Lafayette, Ind.: Purdue University.

Rajarathnam, S., Shashirekha, M. N. and Z. Bano. (1998). Biodegradative and biosynthetic capacities of mushrooms: present and future strategies. CRC Critical Reviews in Biotech. 18(2/3): 91-236.

Rizvi, S. S. H. (1995). Thermodynamic properties of foods in dehydration. In: Rao, M. A. and Rizvi, S. S. H. (Editors) Engineering Properties of Foods. Marcel Dekker, New York. pp. 223-309.
Sogi, D. S., Shivhare, U. S., Garg, S. K., and Bawa, A. S. (2003). Water sorption isotherm and drying characteristics of tomato seeds. Biosystems Engineering 84: 293301.

Tan, D. L. S., K. Miyamoto, K. Ishibashi, K. Matsuda, and T. Satow. (2001). Thin-layer drying of sweet potato chips and pressed grates. Trans. ASAE. 44(3): 669-674.

Thakor, N. J., Sokhansanj, S., Sosulski, F. W. and Yannacopoulos, S. (1999). Mass and dimensional changes of single canola kernels during drying. Journal of Food Engineering 40, 153-160.

Tuley, L. (1996). Swell time for dehydrated vegetables. Intern. Food Ingredients 4(1): $23-27$. 